\title{
Originals
}

\section{Effects of non-esterified fatty acid availability on insulin stimulated glucose utilisation and tissue pyruvate dehydrogenase activity in the rat}

\author{
Y.T.Kruszynska ${ }^{1}$, J.G. McCormack ${ }^{2}$ and N. McIntyre ${ }^{1}$ \\ 1 Department of Medicine, Royal Free Hospital, London and ${ }^{2}$ Department of Biochemistry, Leeds University, Leeds, UK
}

\begin{abstract}
Summary. Fatty acids in cardiac muscle compete with glucose for oxidation, thereby inhibiting glucose utilisation. It is not clear whether a similar mechanism is important in resting skeletal muscle. We used the hyperinsulinaemic euglycaemic clamp technique in conscious rats fasted for $20 \mathrm{~h}$ to examine the effects of increased plasma non-esterified fatty acid levels $(\sim 1 \mathrm{mmol} / \mathrm{l})$ on glucose metabolism. Insulin was infused at $75 \mathrm{mU} / \mathrm{h}$ (plasma insulin, $2.27 \pm 0.21 \mu \mathrm{g} / \mathrm{l})$ or $300 \mathrm{mU} / \mathrm{h}(16.41 \pm 0.47 \mu \mathrm{g} / \mathrm{l})$. An increase in non-esterified fatty acid levels decreased clamp glucose requirement and $3-{ }^{3} \mathrm{H}$-glucose turnover by $35 \%$ $(p<0.001)$ when the higher insulin dose was used but there was no change at the lower dose. At both insulin infusion rates, clamp blood lactate and pyruvate responses suggested inhibition of muscle glycolysis by elevated plasma non-esterified fatty acid concentrations. Quadriceps muscle glycogen deposition during the clamps was enhanced by increased non-esterified fatty acid availability at the lower insulin dose $(p<0.001)$ but not at the higher
\end{abstract}

insulin concentration. Activation of pyruvate dehyrogenase during the clamps was partially inhibited by increased plasma non-esterified fatty acid in the heart, adipose tissue and quadriceps muscle. This was evident at both insulin levels in heart but only at the higher insulin concentration in muscle $(p<0.002)$. The findings are consistent with an inhibition of glycolysis in skeletal muscle of mixed fibre type as a result of increased fatty acid availability. At low rates of glucose flux glycogen synthesis may compensate for decreased glycolysis so that glucose turnover is not decreased. The role of pyruvate dehydrogenase in the "glucose-fatty acid cycle" in muscle may depend on the prevailing plasma insulin concentration and the degree of activation of this enzyme.

Key words: Glucose-fatty acid cycle, non-esterified fatty acids, rat, glucose clamp, glycogen, glycogen synthase, pyruvate dehydrogenase, intermediary metabolites, glucose turnover.
Inhibition of glucose uptake and oxidation in rat diaphragm and cardiac muscle by increased fatty acid oxidation was first demonstrated by Randle and colleagues [1]. They coined the term "glucose-fatty acid cycle" and suggested that increased availability of non-esterified fatty acids (NEFA) in obesity and diabetes may play an important role in the glucose intolerance and tissue insensitivity to insulin [2].

Glucose tolerance was impaired when plasma NEFA concentrations were raised in normal man, by infusion of lipids $[3,4]$ or administration of heparin with a fat meal [5]. As liver and skeletal muscle are quantitatively the most important tissues for disposal of an oral glucose load $[6,7]$, it is necessary to postulate that increased fatty acid availability impairs glucose uptake by these tissues. Decreased insulin-stimulated muscle glucose uptake and impaired suppression of hepatic glucose production by insulin in rats fed a high fat diet for several weeks would support this $[8,9]$. However, the effects of an acute increase in fatty acid availability on skeletal muscle glucose utilisation remain controversial. Schonfeld and Kipnis [10] using rat diaphragm, and others using the isolated perfused rat hindquarter [11-13] could not demonstrate inhibition of glucose metabolism by increased fatty acid availability. A sparing effect of fatty acids on muscle glucose metabolism has, however, been demonstrated in well oxygenated perfused skeletal muscle [14] and in the exercising rat [15].

Recent studies in conscious rats employing the glucose clamp technique in conjunction with labelled 2-deoxyglucose suggested that an acute elevation of plasma NEFA may actually increase insulin stimulated glucose uptake in skeletal muscle [16]. These findings are at variance with the demonstration of decreased whole body glucose disposal in man under conditions of a hyperinsulinaemic glucose clamp when plasma NEFA levels are increased by 
Table 1. Plasma insulin, triglyceride and non-esterified fatty acid (NEFA) levels in the experimental rats

\begin{tabular}{|c|c|c|c|c|c|c|}
\hline \multirow[b]{2}{*}{ Insulin dose (mU/h) } & \multirow[t]{2}{*}{ Basal } & \multirow[t]{2}{*}{ Ad libitum fed } & \multicolumn{2}{|l|}{ Clamp } & \multicolumn{2}{|c|}{ Clamp with Intralipid } \\
\hline & & & 75 & 300 & 75 & 300 \\
\hline $\bar{n}$ & 24 & 6 & 6 & 6 & 6 & 6 \\
\hline Triglyceride (mmol/l) & $0.69 \pm 0.02$ & $0.87 \pm 0.09$ & $0.37 \pm 0.02$ & $0.37 \pm 0.02$ & $1.10 \pm 0.06$ & $0.85 \pm 0.09$ \\
\hline $\mathrm{NEFA}(\mu \mathrm{mol} / \mathrm{l})$ & $912 \pm 38$ & $191 \pm 21$ & $103 \pm 13$ & $75 \pm 13$ & $1552 \pm 106$ & $1334 \pm 110$ \\
\hline
\end{tabular}

Mean \pm SEM. $n=6$ in each group.

Plasma insulin, triglyceride and NEFA concentrations in the basal state before the clamps did not differ between groups and for clarity have been pooled

Table 2. Glucose kinetics in rats fasted for $20 \mathrm{~h}$ and during the hyperinsulinaemic glucose clamps

\begin{tabular}{|c|c|c|c|c|c|}
\hline \multirow[b]{2}{*}{ Insulin dose (mU/h) } & \multirow[t]{2}{*}{ Basal } & \multicolumn{2}{|l|}{ Clamp } & \multicolumn{2}{|c|}{ Clamp with Intralipid $^{a}$} \\
\hline & & 75 & 300 & 75 & 300 \\
\hline$n$ & 24 & 6 & 6 & 6 & 6 \\
\hline Plasma glucose $(\mathrm{mmol} / \mathrm{l})$ & $6.2 \pm 0.1$ & $6.5 \pm 0.2$ & $6.6 \pm 0.1$ & $6.4 \pm 0.1$ & $6.5 \pm 0.1$ \\
\hline $\begin{array}{l}{ }^{3} \mathrm{H} \text {-glucose turnover } \\
\left(\mu \mathrm{mol} \cdot \mathrm{min} \cdot \mathrm{kg}^{-1}\right)\end{array}$ & $61 \pm 2$ & $138 \pm 7$ & $250 \pm 13^{c}$ & $122 \pm 8$ & $163 \pm 7^{\mathfrak{c}}$ \\
\hline $\begin{array}{l}\text { Residual hepatic glucose output } \\
\left(\mu \mathrm{mol} \cdot \min \cdot \mathrm{kg}^{-1}\right)\end{array}$ & - & $6 \pm 3$ & $-13 \pm 4^{b}$ & $10 \pm 6$ & $-9 \pm 4^{b}$ \\
\hline
\end{tabular}

Mean \pm SEM.

${ }^{a}$ By analysis of variance the decrease with Intralipid was significant for ${ }^{3} \mathrm{H}$-glucose turnover and clamp glucose requirement (both $p<0.001$ );

b, c $p<0.002, p<0.001$ compared with animals infused with $75 \mathrm{mU}$ insulin/h (by analysis of variance)

concomitant infusion of a triglyceride emulsion (Intralipid) and heparin [17-19].

We have therefore used the glucose clamp technique to examine the effects of elevated plasma NEFA on insulin-stimulated glucose disposal and muscle glycogen deposition in conscious rats. Since the demonstration of an interaction between lipid and glucose metabolism in skeletal muscle may depend on glucose flux $[18,20]$, glucose clamps were performed (a) at a plasma insulin concentration similar to that found in ad libitum fed rats and (b) at a supraphysiological insulin concentration, which would be expected to result in near maximal rates of insulin-stimulated muscle glucose uptake.

In heart [21-23] and red skeletal muscle [20, 21], increased fatty acid and ketone body oxidation inhibits glucose oxidation at the level of pyruvate dehydrogenase (PDH). The decrease in muscle PDH activity during starvation [24-26] is considered to play a key role in the starvation-induced decrease in whole body glucose turnover $[24,27]$. As increased fatty acid availability may play a major role in decreasing muscle PDH activity $[26,28]$ we measured the activity of this enzyme in peripheral tissues both basally and at the end of the glucose clamps.

\section{Materials and methods}

\section{Animals}

Syngeneic male Ludwig-Wistar rats weighing 280-310 g were maintained on standard laboratory chow and were handled daily for four weeks before the study. Indwelling cannulae for metabolic studies were implanted under ether anaesthesia in the external jugular and femoral veins $20 \mathrm{~h}$ before the experiment, and rats fasted from the time of surgery.

\section{Radioisotopic glucose turnover and euglycaemic clamp studies}

Insulin sensitivity was assessed by the euglycaemic clamp technique in rats fasted for $20 \mathrm{~h}$. All blood samples were taken from conscious, unrestrained animals.

After basal blood samples were taken a primed continuous infusion of $3-{ }^{3} \mathrm{H}$-glucose $(0.03 \mu \mathrm{Ci} / \mathrm{min})$ diluted in water was begun and continued for $60 \mathrm{~min}$. Blood samples $(150 \mu \mathrm{l})$ were taken from the femoral venous cannula at 50 and $55 \mathrm{~min}$ for determination of plasma glucose concentration and specific activity. From +60 min neutral soluble insulin (Humulin S, Eli Lilly, Basingstoke, UK) diluted in Haemaccel was infused for $2 \mathrm{~h}$ through one limb of a double lumen cannula (Miles, Stoke Poges, UK) connected to the jugular venous cannula at either $75 \mathrm{mU} / \mathrm{h}$ (low-dose, $n=12$ ) or $300 \mathrm{mU} / \mathrm{h}$ (high-dose, $n=12$ ).

The insulin solution also contained glucose tracer to give an increased infusion rate of $0.12 \mu \mathrm{Ci} / \mathrm{min}$ of $3{ }^{3} \mathrm{H}$-glucose. At the higher insulin infusion rate potassium chloride was also infused at a rate of $0.15 \mathrm{mmol} / \mathrm{h}$ during the clamp. In half of the insulin-infused rats plasma NEFA levels were raised during the clamps by a priming bolus of heparin $(10 \mathrm{U}$ at $+60 \mathrm{~min})$ followed by a constant infusion of heparin $(40 \mathrm{U} / \mathrm{h})$ and a $20 \%$ weight/volume triglyceride emulsion (Intralipid, Kabivitrum Ltd, Uxbridge, UK) at $0.6 \mathrm{ml} / \mathrm{h}$ delivered through the injection port of the double lumen cannula.

Blood samples for glucose $(30 \mu \mathrm{l})$ were taken at 5-10 min intervals and blood glucose maintained at $4.0 \mathrm{mmol} / \mathrm{l}$ by a variable infusion of $500 \mathrm{~g} / \mathrm{l}$ glucose in water. Blood samples were taken for insulin, triglyceride and NEFA estimation at 120 and $180 \mathrm{~min}(350 \mu \mathrm{l})$, for intermediary metabolites $(200 \mu \mathrm{l})$ at $180 \mathrm{~min}$, and for glucose specific activity $(200 \mu \mathrm{l})$ at 165 and $175 \mathrm{~min}$, and were replaced with an equal 
Table 3. Blood intermediary metabolite concentrations in rats fasted for $20 \mathrm{~h}$ and during the glucose clamps

\begin{tabular}{|c|c|c|c|c|c|}
\hline \multirow[b]{2}{*}{ Insulin dose $(\mathrm{mU} / \mathrm{h})$} & \multirow[t]{2}{*}{ Basal } & \multicolumn{2}{|l|}{ Clamp } & \multicolumn{2}{|c|}{ Clamp with Intralipid $^{d}$} \\
\hline & & 75 & 300 & 75 & 300 \\
\hline$n$ & 24 & 6 & 6 & 6 & 6 \\
\hline Pyruvate $(\mu \mathrm{mol} / \mathrm{l})$ & $42 \pm 2$ & $114 \pm 14^{a}$ & $161 \pm 21^{\mathrm{b}}$ & $80 \pm 11$ & $95 \pm 11$ \\
\hline Alanine $(\mu \mathrm{mol} / 1)$ & $240 \pm 9$ & $356 \pm 24^{c}$ & $368 \pm 31^{\mathrm{a}}$ & $301 \pm 21$ & $303 \pm 13$ \\
\hline
\end{tabular}

Mean \pm SEM. Blood metabolite values in the basal state before the clamps did not differ between groups and for clarity have been pooled. ${ }^{\mathrm{a}} p<0.02,{ }^{\mathrm{b}} p<0.005,{ }^{\mathrm{c}} p<0.001$ compared to values in the same 6 rats in the basal state (paired $t$-test); ${ }^{\mathrm{d}}$ By analysis of variance, blood metabolite concentrations during the clamps with Intralipid were significantly different from those during clamps without Intralipid (alanine, $p<0.05$; pyruvate, $p<0.01$; lactate, glycerol and 3-hydroxybutyrate, all $p<0.001$ )

volume of fresh washed rat erythrocytes in $0.15 \mathrm{~mol} / \mathrm{l} \mathrm{NaCl}$. At $+180 \mathrm{~min}$, while maintaining the clamp, rats were anaesthetised by an i.v. injection of $15 \mathrm{mg}$ amylobarbitone (100 g/l, Eli Lilly) and heart, epididymal adipose tissue and quadriceps skeletal muscle were freeze clamped within $15 \mathrm{~s}$, ground under liquid nitrogen and stored at $-70^{\circ} \mathrm{C}$ for up to 2 months until assayed for glycogen content, glycogen synthase and PDH activities. Tissue was also obtained from rats that were anaesthetised in the basal state $(20 \mathrm{~h}$ fasted infused with Haemaccel alone) and a group of rats fed ad libitum.

For determination of glucose specific activity, plasma was immediately deproteinised with $\mathrm{Ba}(\mathrm{OH})_{2} / \mathrm{ZnSO}_{4}[29]$ and the neutral extract passed down a column of $\mathrm{AG} 2 \times 8$ anion exchange resin (BioRad, Richmond, Calif., USA). The column was eluted with deionised water, and the eluate evaporated. Radioactivity was determined in a Philips PW 4700 liquid scintillation counter (NV Philips' Gloeilampenfabrieken, Lelyweg, Holland). Minimum recovery after deproteinisation, neutralisation and evaporation was $90 \%$. Triplicate samples of the basal and clamp infusion fluids were processed as for the plasma samples. Glucose turnover was estimated from the formula:

Glucose turnover $=\frac{\text { tracer infused }(\mathrm{DPM} / \mathrm{min})}{\text { glucose specific activity }(\mathrm{DPM} / \mu \mathrm{mol})}$

\section{Enzyme assays}

Glycogen synthase was measured in the absence (active) and presence (total) of $10 \mathrm{mmol} / \mathrm{l}$ glucose- 6 -phosphate as previously described [30]. PDH was measured spectrophotometrically [31]. Total $\mathrm{PDH}$ was measured after incubation of extracts with purified pig heart PDH phosphate phosphatase [31]. One unit of enzyme is defined as the amount converting $1 \mu \mathrm{mol} / \mathrm{min}$ of substrate to product at $30^{\circ} \mathrm{C}$.

\section{Other analyses}

Glycogen was assayed by the amyloglucosidase method [32]. Blood for estimation of intermediary metabolites was deproteinised with perchloric acid $(0.6 \mathrm{~mol} / \mathrm{l})$ and the extract assayed for lactate, pyruvate, alanine, glycerol and 3-hydroxybutyrate by enzymic fluorimetric methods [33] in an LS50 luminescence spectrometer (Perkin Elmer, Beaconsfield, UK). Plasma insulin was determined by radioimmunoassay [34] using a rat or human insulin standard (Novo Industri, Bagsvaerd, DK) as appropriate. Blood glucose was measured by a glucose oxidase method (Yellow Springs Glucose Analyser, Clandon Scientific, London, UK). Plasma NEFA were determined using an acyl-CoA oxidase based colorimetric kit (WAKO NEFA-C; Wako Chemicals GmbH, Neuss, FRG) and plasma triglyceride with a GPO-PAP kit (Boehringer, Mannheim, FRG).

\section{Statistical analysis}

Results are presented as mean \pm SEM. Significant differences between groups were assessed by Student's paired or unpaired $t$-test or analysis of variance as appropriate.

\section{Results}

\section{Plasma lipid and insulin levels (Table 1)}

During the glucose clamps, plasma NEFA fell to similar low levels at both insulin infusion rates. Infusion of Intralipid and heparin during the glucose clamps resulted in an increase in circulating NEFA; levels at the end of the clamp were then similar to those in the basal state. Plasma triglyceride concentrations were decreased during the clamp compared with the basal state $(p<0.001$, Table 1$)$. Infusion of Intralipid and heparin increased plasma triglyceride concentrations; levels at the end of the clamp were approximately 1.5-2 times those in the basal state.

Steady state plasma insulin concentrations during the glucose clamps (human insulin standard) were $2.27 \pm 0.21 \mu \mathrm{g} / 1 \quad(66 \pm 6 \mathrm{mU} / \mathrm{l}) \quad$ and $16.41 \pm 0.47 \mu \mathrm{g} / \mathrm{l}$ $(474 \pm 14 \mathrm{mU} / \mathrm{l})$ at insulin infusion rates of $75 \mathrm{mU} / \mathrm{h}$ and $300 \mathrm{mU} / \mathrm{h}$ respectively $(n=12)$. Circulating insulin levels during the glucose clamps were not affected by infusion of Intralipid and heparin (Table 1).

\section{Glucose kinetics and blood intermediary metabolite concentrations}

Blood glucose concentrations were successfully maintained during the clamp studies and were not different in the four groups (Table 2). The coefficient of variation of blood glucose calculated for each animal was $3.94 \pm 1.7$ (SD)\%. Glucose turnover was increased approximately twofold by the low dose insulin clamp and fourfold by the high dose insulin clamp (Table 2). When plasma triglyceride and NEFA levels were elevated during the clamps by infusion of Intralipid and heparin, there was a significant decrease in insulin stimulated isotopically-measured glucose turnover $(\mathrm{F}=33.32, p<0.001)$. Analysis of variance indicated a significant interaction between clamp insulin infusion rate and the effect of Intralipid $(F=15.10$, 
Kruszynska et al.: Fatty acids and muscle glucose metabolism in vivo

Table 4. Heart and skeletal muscle glycogen concentrations in rats in the fasting and ad libitum fed states and at the end of a hyperinsulinaemic glucose clamp

\begin{tabular}{|c|c|c|c|c|}
\hline \multirow[t]{2}{*}{ Glycogen ( $\mu \mathrm{mol} / \mathrm{g}$ wet weight) } & \multirow[t]{2}{*}{ Fasted rats } & \multirow[t]{2}{*}{ Ad libitum fed rats } & \multicolumn{2}{|l|}{ Clamped rats ${ }^{\mathrm{b}}$} \\
\hline & & & $75 \mathrm{mU}$ insulin $/ \mathrm{h}$ & $300 \mathrm{mU}$ insulin $/ \mathrm{h}$ \\
\hline $\begin{array}{l}\text { Heart } \\
\quad \text { - Intralipid } \\
\quad+\text { Intralipid }\end{array}$ & $\begin{array}{l}16.9 \pm 1.8 \\
-\end{array}$ & $\begin{array}{l}20.7 \pm 2.6 \\
-\end{array}$ & $\begin{array}{l}23.3 \pm 2.7 \\
32.0 \pm 2.8\end{array}$ & $\begin{array}{l}21.1 \pm 2.5 \\
38.5 \pm 2.4\end{array}$ \\
\hline $\begin{array}{l}\text { Muscle } \\
\quad \text { - Intralipid } \\
\text { + Intralipid }\end{array}$ & $\begin{array}{l}15.1 \pm 2.4 \\
-\end{array}$ & $\begin{array}{l}30.8 \pm 2.2^{\mathrm{a}} \\
-\end{array}$ & $\begin{array}{l}22.9 \pm 0.9 \\
34.8 \pm 3.4\end{array}$ & $\begin{array}{l}41.6 \pm 2.8 \\
37.5 \pm 1.6\end{array}$ \\
\hline
\end{tabular}

Mean \pm SEM. $n=6$ in each group. " $p<0.001$ compared to fasted rats; ${ }^{b}$ By analysis of variance the increase in glycogen from "fasting" to "clamp" was significant in muscle both in the absence and presence of Intralipid $(p<0.001)$ and in heart in the presence of Intralipid $(p<0.001)$

Table 5. Heart and skeletal muscle glycogen synthase activity in rats in the fasting and ad libitum fed states and at the end of a $2 \mathrm{~h}$ hyperinsulinaemic glucose clamp

\begin{tabular}{|c|c|c|c|c|c|c|}
\hline \multirow{2}{*}{$\begin{array}{l}\text { Glycogen synthase } \\
\text { (U/g wet weight) }\end{array}$} & \multirow[t]{2}{*}{ Fasting } & \multirow[t]{2}{*}{ Ad libitum fed } & \multicolumn{2}{|l|}{ Clamp } & \multicolumn{2}{|c|}{ Clamp with Intralipid $^{\mathrm{d}}$} \\
\hline & & & $75 \mathrm{mU} / \mathrm{h}$ insulin & $300 \mathrm{mU} / \mathrm{h}$ insulin & $75 \mathrm{mU} / \mathrm{h}$ insulin & $300 \mathrm{mU} / \mathrm{h}$ insulin \\
\hline \multicolumn{7}{|l|}{ Muscle } \\
\hline Total & $2.73 \pm 0.14$ & $2.92 \pm 0.11$ & $2.56 \pm 0.13$ & $2.59 \pm 0.18$ & $2.50 \pm 0.16$ & $2.82 \pm 0.11$ \\
\hline$\%$ Active & $30.5 \pm 1.1$ & $46.2 \pm 3.5^{\mathrm{a}}$ & $41.0 \pm 2.6$ & $50.8 \pm 3.6^{c}$ & $37.9 \pm 2.4$ & $37.3 \pm 2.2$ \\
\hline \multicolumn{7}{|l|}{ Heart } \\
\hline$\%$ Active & $11.5 \pm 1.8$ & $37.9 \pm 2.2^{\mathrm{b}}$ & $10.1 \pm 1.4$ & $17.4 \pm 1.8$ & $9.9 \pm 1.0$ & $10.0 \pm 1.2$ \\
\hline
\end{tabular}

Mean \pm SEM. $n=6$ in each group. ${ }^{\mathrm{a}} p<0.002 ;{ }^{\mathrm{b}} p<0.001$ compared with fasted rats; ${ }^{\mathrm{c}} p<0.001$ compared with fasted rats (by analysis of variance); ${ }^{d}$ By analysis of variance the decreased activation of glycogen synthase during the clamps with Intralipid was significant in both skeletal muscle and heart (muscle: GSa, $p<0.005 ; \mathrm{GS} \% \mathrm{a}, p<0.02$; heart: GS\%a, $p<0.005$ )

$p<0.002)$. Thus, at the lower insulin infusion rate $(75 \mathrm{mU} / \mathrm{h})$ the decrease in glucose turnover $(12.2 \%)$ was not significant. By contrast at $300 \mathrm{mU} / \mathrm{h}$ there was a $35 \%$ decrease $(p<0.001)$ in glucose turnover (Table 2$)$.

Clamp glucose requirement was similarly decreased by the Intralipid infusion during the $300 \mathrm{mU} / \mathrm{h}$ insulin clamp $\quad\left(172.1 \pm 3.4\right.$ vs $262.0 \pm 11.4 \mu \mathrm{mol} \cdot \mathrm{min}^{-1} \cdot \mathrm{kg}^{-1}$, $p<0.001$ ) but not during the $75 \mathrm{mU} / \mathrm{h}$ insulin clamp (Table 2). Residual hepatic glucose production during the clamps, calculated as the difference between glucose turnover and the rate of glucose infusion at steady state was decreased during the high-dose insulin clamp compared with the lower-dose clamp (Table 2, $\mathrm{F}=17.09, p<0.02$ ) but was not affected by infusion of Intralipid.

Blood lactate, pyruvate and alanine concentrations were increased, whereas glycerol and 3-hydroxybutyrate concentrations were decreased during the clamp compared with the basal state (Table 3). Infusion of Intralipid and heparin during the clamps maintained blood glycerol concentrations at basal levels and resulted in incomplete suppression of blood 3-hydroxybutyrate concentrations even at the higher insulin infusion rate (Table 3 ). The increase in blood lactate, pyruvate and alanine concentrations was less marked during the clamps with Intralipid (Table 3).

\section{Skeletal muscle and heart glycogen concentrations}

Quadriceps muscle glycogen concentration was partially depleted by $20 \mathrm{~h}$ of fasting (Table $4, p<0.001$ ). Muscle glycogen deposition was significantly stimulated by the glucose clamps ( $p<0.001$ by analysis of variance). In the absence of Intralipid, glycogen concentration was increased to a greater extent by the high-dose than the lowdose insulin clamps $(41.6 \pm 2.8$ vs $22.9 \pm 0.9 \mu \mathrm{mol} / \mathrm{g}$ wet weight, $p<0.001)$. Intralipid significantly stimulated muscle glycogen deposition during the $75 \mathrm{mU} / \mathrm{h}$ insulin clamp (Table $4, p<0.001$ ) but not during the $300 \mathrm{mU} / \mathrm{h}$ insulin clamp.

No change in cardiac muscle glycogen concentration was found with fasting and there was no stimulation of glycogen deposition by the glucose clamp. Intralipid resulted in significant stimulation of glycogen deposition in the heart during the clamps (Table $4, p<0.001$ by analysis of variance). This effect was independent of insulin dose, so that glycogen concentration at the end of the $300 \mathrm{mU} / \mathrm{h}$ insulin clamp was not significantly different from that at the end of the $75 \mathrm{mU} / \mathrm{h}$ insulin clamp (Table 4).

\section{Skeletal muscle and heart glycogen synthase activity}

Glucose-6-phosphate stimulated (total) glycogen synthase activity in muscle was not different between fasted and fed rats and did not change with the clamps (Table 5). The glucose-6-phosphate independent form of glycogen synthase was significantly higher in fed rats compared with fasted rats (Table 5) and activity was higher at the end of the glucose/insulin infusions than in the fasting state (Table $5, p<0.001$ by analysis of variance). Infusion of Intralipid and heparin during the high-dose clamps resulted in an impairment of insulin activation of muscle glycogen synthase (Table 5). 
Table 6. Tissue pyruvate dehydrogenase (PDH) activity in rats in the fasting and ad libitum fed states and at the end of a $2 \mathrm{~h}$ hyperinsulinaemic glucose clamp

\begin{tabular}{|c|c|c|c|c|c|c|}
\hline \multirow{2}{*}{$\begin{array}{l}\mathrm{PDH} \text { (U/g wet } \\
\text { weight) }\end{array}$} & \multirow[t]{2}{*}{ Fasted } & \multirow[t]{2}{*}{ Ad libitum fed } & \multicolumn{2}{|l|}{ Clamp } & \multicolumn{2}{|c|}{ Clamp with Intralipid $^{c}$} \\
\hline & & & $75 \mathrm{mU}$ insulin $/ \mathrm{h}$ & $300 \mathrm{mU}$ insulin $/ \mathrm{h}$ & $75 \mathrm{mU}$ insulin/h & $300 \mathrm{mU}$ insulin $/ \mathrm{h}$ \\
\hline \multicolumn{7}{|l|}{ Muscle } \\
\hline PDHa & $0.07 \pm 0.01$ & $0.22 \pm 0.03^{\mathrm{a}}$ & $0.10 \pm 0.01$ & $0.19 \pm 0.01^{b}$ & $0.08 \pm 0.01$ & $0.12 \pm 0.01$ \\
\hline $\mathrm{PDH}_{\mathrm{T}}$ & $1.17 \pm 0.07$ & $1.09 \pm 0.08$ & $1.19 \pm 0.07$ & $1.12 \pm 0.07$ & $1.10 \pm 0.05$ & $1.11 \pm 0.06$ \\
\hline$\%$ Active & $5.5 \pm 0.5$ & $20.3 \pm 1.6^{\mathrm{a}}$ & $8.6 \pm 0.90$ & $17.2 \pm 1.5^{\mathrm{b}}$ & $7.2 \pm 0.7$ & $10.7 \pm 0.6$ \\
\hline \multicolumn{7}{|l|}{ Heart } \\
\hline$\%$ Active & $0.6 \pm 0.2$ & $29.8 \pm 2.8^{\mathrm{a}}$ & $20.2 \pm 2.7$ & $22.3 \pm 3.6^{\mathrm{b}}$ & $10.2 \pm 1.5$ & $9.7 \pm 3.2$ \\
\hline \multicolumn{7}{|l|}{ Adipose tissue } \\
\hline $\mathrm{PDHa}$ & $0.02 \pm 0.01$ & $0.10 \pm 0.01^{\mathrm{a}}$ & $0.03 \pm 0.00$ & $0.15 \pm 0.02^{b}$ & $0.03 \pm 0.00$ & $0.10 \pm 0.01$ \\
\hline $\mathrm{PDH}_{\mathrm{T}}$ & $0.26 \pm 0.01$ & $0.28 \pm 0.01$ & $0.27 \pm 0.01$ & $0.28 \pm 0.02$ & $0.28 \pm 0.02$ & $0.27 \pm 0.02$ \\
\hline$\%$ Active & $6.0 \pm 1.6$ & $35.8 \pm 5.3^{\mathrm{a}}$ & $11.1 \pm 0.8$ & $53.2 \pm 4.6^{\mathrm{b}}$ & $8.6 \pm 0.6$ & $38.3 \pm 3.5$ \\
\hline
\end{tabular}

Mean \pm SEM. $n=6$ in each group. ${ }^{\mathrm{a}} p<0.001$ compared to fasted rats; ${ }^{\mathrm{b}} p<0.001$ compared to fasted rats by analysis of variance; ${ }^{\mathrm{c}}$ By analysis of variance the decreased activation of pyruvate dehydrogenase during the clamps with Intralipid was significant in all three tissues (muscle; PDHa, $p<0.001$; PDH \% a, $p<0.002$; heart PDHa, $p<0.005 ; \mathrm{PDH} \%$ a, $p<0.002$; adipose tissue, $\mathrm{PDHa}, p<0.05 ; \mathrm{PDH} \% \mathrm{a}, p<0.02$ )

Heart total glycogen synthase activity was higher in ad libitum fed rats than in $20 \mathrm{~h}$ fasted rats (Table $5, p<0.001$ ). Heart glucose-6-phosphate independent glycogen synthase activity, whether expressed in units/g wet weight or as a percentage of total enzyme activity was also increased in the ad libitum fed rats (Table 5, $p<0.001$ for both). Total glycogen synthase activity in the heart was not affected by the glucose clamps but there was a small increase in the percentage of enzyme in the active form at the end of the $300 \mathrm{mU} / \mathrm{h}$ insulin clamp (Table $5, p<0.05$ ). Intralipid inhibited this activation of heart glycogen synthase by insulin (Table $5, \mathrm{~F}=7.34, p<0.005$ ).

\section{Skeletal muscle, heart and adipose tissue PDH activity}

Total pyruvate dehydrogenase $\left(\mathrm{PDH}_{\mathrm{T}}\right)$ activity was not different between fasted and fed rats and was unaffected by the glucose clamps in the three tissues studied (Table 6). In the heart, skeletal muscle and adipose tissue the expressed activity of pyruvate dehydrogenase (PDHa and $\mathrm{PDHa} \%$ ) decreased markedly with fasting (Table 6). In all three tissues there was a significant increase in the expressed activity of PDH at the end of the clamps compared with the basal state (Table 6 ),$p<0.001$ by analysis of variance). Whilst in adipose tissue and skeletal muscle activation of $\mathrm{PDH}$ was greater during the high insulindose clamp (Table 6), in heart PDH activation was not further enhanced by the higher insulin infusion rate. When plasma triglyceride and NEFA levels were elevated during the clamps, there was a $50-60 \%$ decrease in insulin stimulated PDH activity in heart (both insulin doses). In skeletal muscle and adipose tissue increased lipid fuel availability decreased insulin-stimulated PDH activity by $20-40 \%$ during the high-dose insulin clamps but not during the low-dose insulin clamps (Table 6). Even in the presence of Intralipid PDHa \% was increased at the end of the clamps compared to rats in the basal state (Table 6 ; heart, $\mathrm{F}=13.80, p<0.005$; adipose tissue, $\mathrm{F}=39.96$, $p<0.001$; quadriceps muscle, $\mathrm{F}=22.99, p<0.001$ ).

\section{Discussion}

In keeping with studies in man $[18,19]$ we have shown that a physiological elevation of plasma NEFA concentrations in rats inhibits insulin-stimulated glucose utilisation during a glucose clamp. This effect was, however, dependent on the insulin infusion rate. Thus, at plasma insulin concentrations similar to those found in ad libitum fed rats, glucose turnover and clamp glucose requirement during Intralipid infusion were not statistically significantly lower than in rats infused with insulin alone. By contrast at supraphysiological insulin concentrations, expected to produce near maximal rates of insulin-stimulated glucose utilisation, increased plasma NEFA levels inhibited glucose metabolism by $35 \%$. These findings concur with those of Ferrannini et al. [18] who found a strong correlation between glucose flux and the percent inhibition of glucose uptake by fatty acids during a clamp.

We are unable to confirm the stimulatory effect of increased NEFA on systemic glucose utilisation reported by Jenkins et al. [16] who used an insulin infusion rate similar to our low dose $(75 \mathrm{mU} / \mathrm{h})$ and an identical Intralipid/heparin infusion protocol. The reason for this difference is unclear but may be related to the higher insulin sensitivity of the control rats in the present study. Not only was clamp glucose requirement $55 \%$ higher, but hepatic glucose production was completely suppressed during the low-dose insulin clamp in contrast to the less than $50 \%$ suppression found by Jenkins et al. [16].

Under conditions of a hyperinsulinaemic glucose clamp glucose disposal is largely determined by skeletal muscle [35-37]. Glucose taken up by muscle is either incorporated into glycogen or metabolised by glycolysis to pyruvate. $\mathrm{PDH}$ is rate-limiting for oxidation of pyruvate and is thought to play a key role in the "glucose-fatty acid cycle" in the heart [23]. In the current study, activation of $\mathrm{PDH}$ in quadriceps muscle and adipose tissue was less sensitive to insulin than in the heart. The poor stimulation of muscle PDH during the low-dose insulin clamps (Table 6) suggests that factors other than insulin and lipid avail- 
ability must also play a role in the regulation of this enzyme in muscle. This is in keeping with the delayed reactivation of muscle PDH on refeeding of fasted rats [25] and the lack of effect of inhibition of lipid oxidation on the starvation-induced decrease in muscle PDH activity [26, 38].

In heart elevated NEFA during the clamps inhibited activation of $\mathrm{PDH}$ at both physiological and supraphysiological insulin concentrations. In quadriceps muscle, however, increased NEFA had no effect on PDH activity at the lower insulin dose and caused less inhibition at the higher dose than in heart ( $38 \%$ vs $57 \%$, Table 6 ). Holness et al. [26] found that increasing plasma NEFA by administration of corn oil and heparin to rats, accelerated the starvation-induced decline in $\mathrm{PDH}_{\mathrm{a}}$ in oxidative muscles but not in muscles with a high proportion of glycolytic fibres. It is possible that examination of more oxidative muscles which share some features with cardiac muscle would have demonstrated an effect of fatty acids on PDH activity at the lower insulin level. We chose, however, to examine quadriceps as this muscle consists of a mixture of red and white fibres and is more representative of the bulk of skeletal muscle.

Inhibition of PDH in adipose tissue by increased fatty acid availability provides a mechanism for chanelling glucose to glycerol-3-phosphate which is important for fatty acid esterification. The inhibition of PDH activity in skeletal muscle and heart during the clamps with Intralipid is consistent with in vitro studies showing inhibition of pyruvate oxidation by increased availability of fatty acids and ketone bodies [20,21], and supports a role for PDH in the "glucose-fatty acid cycle" in these tissues. However, by contrast with the heart, it would appear that in resting quadriceps muscle the importance of PDH in the "glucose-fatty acid cycle" is dependent on the plasma insulin level and thus on glucose flux and the extent of activation of PDH.

Although quadriceps muscle PDH and whole body glucose disposal were not affected by increased lipid availability at low-dose insulin, it is clear that there was a major effect on glucose metabolism consistent with the operation of the "glucose-fatty acid cycle" in muscle under these conditions. Thus increased plasma NEFA enhanced muscle glycogen deposition during the low-dose insulin clamp, an effect also seen in the heart (Table 4). Previous studies $[15,20,39]$ have shown that enhanced glycogen synthesis in heart and red skeletal muscle when lipid oxidation is increased is associated with an increase in tissue glucose-6-phosphate secondary to inhibition of glycolysis at the level of phosphofructokinase $[15,39,40]$. Although we did not measure glucose-6-phosphate concentrations, increased muscle glycogen deposition but unchanged glucose turnover at low-dose insulin is consistent with an inhibition of glycolytic flux by increased fatty acid availability. The smaller rise in blood lactate and pyruvate concentrations during the clamps with Intralipid in the presence of unchanged residual hepatic glucose production and either unchanged or decreased total glucose turnover is also consistent with decreased muscle glycolysis.

Quadriceps muscle glycogen deposition during the high-dose insulin clamps was approximately three-fold that at the lower insulin dose. At these high rates of glycogen synthesis, increased NEFA availability had no stimulatory effect on glycogen deposition. Decreased glucose turnover during the high-dose insulin clamps by Intralipid is consistent with an inhibition of muscle hexokinase and glucose transport secondary to increased glucose-6-phosphate concentrations [1].

Increased glycogen deposition during the clamps with Intralipid was not due to increased glycogen synthase activity. Indeed at the end of the high-dose insulin clamps, activation of muscle and heart glycogen synthase was impaired when elevated NEFA levels were maintained (Table 5). In the heart this might be explained by an inhibitory effect of the increased glycogen concentration $[41,42]$. However, this cannot explain the impaired activation of glycogen synthase in muscle since muscle glycogen was not increased by Intralipid at the higher insulin concentration.

In contrast to reports using isolated muscle preparations [10] or the perfused rat hindquarter [11-13], our findings support the idea that the "glucose-fatty acid cycle" is operative in resting skeletal muscle. Rennie and Holloszy [15] drew attention to the importance of adequate tissue oxygenation for demonstration of an effect of increased NEFA on glucose metabolism in muscle. Oxygenation is a problem in in vitro studies [15]. In this respect the current in vivo studies offer a distinct advantage and may in part explain our ability to demonstrate an effect of NEFA on glucose metabolism in resting skeletal muscle of mixed fibre type. It would appear that at plasma insulin concentrations similar to those found in fed rats, increased glycogen synthesis compensates for decreased glycolytic flux so that whole body glucose disposal is not decreased. However, at high rates of glucose flux induced by supraphysiological insulin concentrations, rates of glycogen synthesis are already high; under these circumstances inhibition of glycolysis results in decreased muscle glucose utilisation.

Acknowledgements. The study was supported by the British Diabetic Association, the British Heart Foundation, the Medical Research Council and the Lister Institute. JG McCormack is a Lister Institute Research Fellow.

\section{References}

1. Randle PJ, Newsholme EA, Garland PB (1964) Regulation of glucose uptake by muscle. Effects of fatty acids, ketone bodies pyruvate, and of alloxan - diabetes and starvation, on the uptake and metabolic fate of glucose in rat heart and diaphragm muscles. Biochem J 93: 652-665

2. Randle PJ, Garland PB, Hales CN, Newsholme EA (1963) The glucose fatty acid cycle. Its role in insulin sensitivity and the metabolic disturbances of diabetes mellitus. Lancet I: 785-789

3. Felber JP, Vannotti A (1964) Effect of fat infusion on glucose tolerance and insulin plasma levels. Med Exp 10: 153-156

4. Gomez F, Jequier E, Chabot V, Buber V, Felber JP (1972) Carbohydrate and lipid oxidation in normal human subjects: its influence on glucose tolerance and insulin response to glucose. Metabolism 21: 381-391

5. Kipnis DM, Schalch DS (1964) The impairment of carbohydrate tolerance by elevated plasma free fatty acids. J Clin Invest 434 : $1283-1286$ 
6. Katz LD, Glickman MG, Rapopart S, Ferrannini E, DeFronzo RA (1983) Splanchnic and peripheral disposal of oral glucose in man. Diabetes 32: 675-679

7. Ferrannini E, Bjorkman O, Reichard GA, Pilo A, Olsson M, Wahren J, DeFronzo RA (1985) The disposal of an oral glucose load in healthy subjects. A quantitative study. Diabetes 34: 580588

8. Kraegen EW, James DE, Storlien LH, Burleigh KM, Chisholm DJ (1986) In vivo insulin resistance in individual peripheral tissues of the high fat fed rat: assessment by euglycaemic clamp plus deoxyglucose administration. Diabetologia 29: 192-198

9. Storlien LH, James DE, Burleigh KM, Chisholm DJ, Kraegen EW (1986) Fat feeding causes widespread in vivo insulin resistance, decreased energy expenditure, and obesity in rats. Am J Physiol 251: E576-E583

10. Schonfeld G, Kipnis D (1968) Effects of fatty acids on carbohydrate and fatty acid metabolism of rat diaphragm. Am J Physiol 215: $513-522$

11. Goodman MN, Berger M, Ruderman NB (1974) Glucose metabolism in rat skeletal muscle at rest. Effect of starvation, diabetes, ketone bodies and free fatty acids. Diabetes 23:881-888

12. Berger M, Hagg SA, Goodman MN, Ruderman NB (1976) Glucose metabolism in perfused skeletal muscle. Effects of starvation, diabetes, fatty acids, acetoacetate, insulin and exercise on glucose uptake and disposition. Biochem J 158: 191-202

13. Ruderman NB, Goodman MN, Conover CA, Berger M (1979) Substrate utilisation in perfused skeletal muscle. Diabetes 28 [Suppl.1]: 13-17

14. Rennie MJ, Winder WW, Holloszy JO (1976) A sparing effect of increased plasma fatty acids on muscle and liver glycogen content in the exercising rat. Biochem J 156: 647-655

15. Rennie MJ,Holloszy JO (1977) Inhibition of glucose uptake and glycogenolysis by availability of oleate in well-oxygenated perfused skeletal muscle. Biochem J 168: 161-170

16. Jenkins AB, Storlien LH, Chisholm DJ, Kraegen EW (1988) Effects of nonesterified fatty acid availability on tissue-specific glucose utilisation in rats in vivo. J Clin Invest 82: 293-299

17. Thiebaud D, DeFronzo RA, Jacot E, Golay A, Achenson K, Maedor E, Jequier E, Felber JP (1982) Effect of long chain triglyceride infusion on glucose metabolism in man. Metabolism 31: 1128-1136

18. Ferrannini E, Barrett EJ, Bevilacqua S, DeFronzo RA (1983) Effect of fatty acids on glucose production and utilisation in man. J Clin Invest 72: 1737-1747

19. Lee KU, Lee HK, Koh CS, Min HK (1988) Artificial induction of intravascular lipolysis by lipid-heparin infusion leads to insulin resistance in man. Diabetologia 31:285-290

20. Maizels EZ, Ruderman NB, Goodman MN, Lau D (1977) Effect of acetoacetate on glucose metabolism in the soleus and extensor digitorum longus muscles of the rat. Biochem J 162: $557-$ 568

21. Garland PB, Newsholme EA, Randle PJ (1964) Regulation of glucose uptake by muscle. Effects of fatty acids and ketone bodies, and of alloxan-diabetes and starvation, on pyruvate metabolism and on lactate/pyruvate and L-glycerol 3-phosphate/dihydroxyacetone phosphate concentration ratios in rat heart and rat diaphragm muscles. Biochem J 93: 665-678

22. Wieland O, Funcke HV, Loffler G (1971) Interconversion of pyruvate dehydrogenase in rat heart muscle upon perfusion with fatty acids or ketone bodies. FEBS Lett 15: 295-298

23. Randle PJ (1986) Fuel selection in animals. Biochem Soc Trans 14: 799-806

24. Kruszynska YT, McCormack JG (1989) Effect of nutritional status on insulin sensitivity in vivo and tissue enzyme activities in the rat. Biochem J 258: 699-707

25. Sugden MC, Holness MJ (1989) Effects of re-feeding after prolonged starvation on pyruvate dehydrogenase activities in heart, diaphragm and selected skeletal muscles of the rat. Biochem $\mathbf{J}$ 262: 669-672

26. Holness MI, Lin Y-L, Sugden MC (1989) Time courses of the responses of pyruvate dehydrogenase activities to short-term star- vation in diaphragm and selected muscles of the rat. Biochem J 264: 771-776

27. Issad T, Penicaud L, Ferre P, Kande J, Baudon MA, Girard J (1987) Effects of fasting on tissue glucose utilisation in conscious resting rats. Major glucose-sparing effect in working muscles. Biochem J 246: 241-244

28. French TJ, Goode AW, Holness MJ, MacLennan PA, Sugden MC (1988) The relationship between changes in lipid fuel availability and tissue fructose 2,6-bisphosphate concentrations and pyruvate dehydrogenase complex activities in the fed state. Biochem J 256: 935-939

29. Somogyi MJ (1945) Determinations of blood sugar. J Biol Chem 160: $69-73$

30. Kruszynska YT, Home PD (1988) Liver and muscle insulin sensitivity, glycogen concentration and glycogen synthase activity in a rat model of non-insulin-dependent diabetes. Diabetologia 31 304-309

31. McCormack JG, Edgell NJ, Denton RM (1982) Studies on the interactions of $\mathrm{Ca}^{2+}$ and pyruvate in the regulation of rat heart pyruvate dehydrogenase activity. Effects of starvation and diabetes. Biochem J 202: 419-427

32. Keppler D, Decker K (1974) Glycogen determination with amyloglucoidase. In: Bergmeyer HU (ed) Methods of enzymatic analysis. Academic Press, New York, pp 1127-1131

33. Lloyd B, Burrin J, Smythe P, Alberti KGMM (1978) Enzymatic fluorimetric continuous flow assays for blood glucose, lactate, pyruvate, alanine, glycerol and 3-hydroxybutyrate. Clin Chem 24: $1724-1729$

34. Heding LG (1972) Determination of total serum insulin (IRI) in insulin treated diabetic patients. Diabetologia 8:260-266

35. Kruszynska YT, Home PD, Alberti KGMM (1986) In vivo regulation of liver and skeletal muscle glycogen synthase activity by glucose and insulin. Diabetes 35: 662-667

36. Kraegen EW, James DE, Jenkins AB, Chisholm DJ (1985) Dose response curves for in vivo insulin sensitivity in individual tissues in rats. Am J Physiol 248: E353-E362

37. James DE, Jenkins AB, Kraegen EW (1985) Heterogeneity of insulin action in individual muscles in vivo: euglycaemic clamp studies in rats. Am J Physiol 248: E567-E574

38. Caterson ID, Fuller SJ, Randle PJ (1982) Effect of fatty acid oxidation inhibitor 2-tetradecylglycidic acid on pyruvate dehydrogenase complex activity in starved and alloxan-diabetic rats. Biochem J 208: 53-60

39. Newsholme EA, Randle PJ (1964) Regulation of glucose uptake by muscle. Effects of fatty acids, ketone bodies and pyruvate, and of alloxan-diabetes, starvation, hypophysectomy and adrenalectomy, on the concentrations of hexose phosphates, nucleotides and inorganic phosphate in perfused rat heart. Biochem $\mathrm{J} 93$ : $641-651$

40. Zorzano A, Balon TW, Brady LJ, Rivera P, Garetto LP, Young JC, Goodman MN, Ruderman NB (1985) Effects of starvation and exercise on concentrations of citrate, hexose phosphates and glycogen in skeletal muscle and heart. Evidence for selective operation of the glucose-fatty acid cycle. Biochem J 232: 585-591

41. Stalmans W, Bollen M, Mvumbi L (1987) Control of glycogen synthesis in health and disease. Diabetes Metab Rev 3: 127-161

42. Danforth WH (1965) Glycogen synthase activity in skeletal muscle. Interconversion of two forms and control of glycogen synthesis. J Biol Chem 240: 588-593

Received: 27 November 1989

and in revised form: 21 February 1990

Dr. Y.T.Kruszynska

Academic Department of Medicine

Royal Free Hospital

Pond Street

London NW3 2QG

UK 